\title{
Effect of different stocking densities on pre-slaughter stress based on respiratory parameters in Nile tilapia (Oreochromis niloticus)
}

\author{
David Geovanni de Almeida Banhara ${ }^{1}$, Wesley Clovis Barbieri Mendonça², \\ Elenice Souza dos Reis Goes ${ }^{2}$, Marcio Douglas Goes ${ }^{3}$, Paulo Henrique \\ BRAZ $^{4} \&$ CLAUCIA APARECIDA HONORATO ${ }^{2 *}$
}

${ }^{1}$ Faculdade de Ciência e Tecnologia de Alimentos - Mestrado em Ciência e Tecnologia de Alimentos Universidade Federal da Grande Dourados, UFGD, Rodovia Dourados - Itahum, km 12, 79804-970, Dourados MS, Brasil.

${ }^{2}$ Faculdade de Ciências Agrárias - Universidade Federal da Grande Dourados, UFGD, Rodovia Dourados - Itahum, km 12, 79804-970, Dourados MS Brasil.

${ }^{3}$ Universidade Estadual do Oeste do Paraná - Departamento de Ciência Animal, Rua Pernambuco, 1777 85960-000 - Marechal Cândido Rondon, PR - Brasil.

${ }^{4}$ Instituto Federal Farroupilha, Campus Frederico Westphalen, Linha 7 de Setembro, BR 386 - KM 40 s/n, Frederico Westphalen - RS - Brasil.

*Corresponding author: clauciaahonorato@gmail.com

\begin{abstract}
This study evaluated whether the resting density after transport in Nile tilapia Oreochromis niloticus shows responses in the respiratory and ionic dynamics related to stress parameters. Forty specimens were submitted to four experimental treatments consisted of control (minimum stress/after removal from water), after transport and one hour of rest, in two stocking densities (50 and $300 \mathrm{~kg}$ of live weight) $/ \mathrm{m}^{3}$ ), with 10 repetitions per treatment. Each fish was considered an experimental unit. Serum stress was evaluated by measuring the glucose and lactate levels, and respiratory dynamics were determined by measuring ionic concentration. The fish in the group after transportation remained in hypoventilation due to high $\mathrm{PCO}_{2}$ values, demonstrating compensatory respiratory acidosis. The stress level was high, indicating increased glycemia. The group of fish in the $300 \mathrm{~kg} / \mathrm{m}^{3}$ density remained in respiratory acidosis. No change in lactate was observed in any of the resting densities. It is concluded that the $50 \mathrm{~kg} /$ $\mathrm{m}^{3}$ density is suitable for pre-slaughter rest because it results in fish with reduced stress responses and with reestablished respiratory responses.
\end{abstract}

Key words: alkalosis, homeostasis, stress, transporting.

Resumo: Efeito de diferentes densidades de estocagem no descanso pré abate sobre esforço respiratório e muscular de tilápia do Nilo (Oreochromis nilticus). Este trabalho teve como objetivo avaliar se a densidade de repouso pós transporte de tilápia-do-Nilo apresenta respostas na dinâmica respiratória e iônica relacionadas com parâmetros de estresse. Foram submetidos ao experimento 40 espécimes distribuídas em quatro tratamentos que foram compostos por: controle (mínimo estresse/após a retirada na água), após o transporte e após o descanso de uma hora em duas densidades de estocagem (50 e $300 \mathrm{~kg}$ de peso vivo/m³), com 10 repetições por tratamento. Cada peixe foi considerado uma unidade experimental. Para mensuração do estresse sérico foram mensurados níveis de glicose e lactato, e a concentração iônicas para determinação da dinâmica respiratória. Os peixes do grupo após o transporte mantiveram-se em hipoventilação devido aos elevados valores de $\mathrm{PCO}_{2}$, demonstrando acidose respiratória compensatória. O nível de estresse foi elevado, demonstrado pelo aumento da glicemia. O grupo de peixes da densidade de $300 \mathrm{~kg} / \mathrm{m}^{3}$ manteve- se em acidose respiratória. Não houve alteração 
na concentração de lactato plasmático. Conclui-se que a densidade de $50 \mathrm{~kg} / \mathrm{m}^{3}$ é a adequada para o descanso pré-abate, pois resulta em peixes com diminuição das respostas de estresse e reestabelecimento das respostas respiratórias.

Palavras-Chave: alcalose, homeostasia, estrese, transporte.

\section{Introduction}

The handling care of fish, from removal from the tank to transport, and during the period before slaughter, directly affects the well-being that can reflect the fillet's sensory quality (Fantini et al. 2020). If pre-slaughter procedures are not carried out with technical criteria, stressing conditions can be increased, reducing the product's shelf life (Goes et al. 2019). Concern for well-being is an aspect that requires attention due to the impact on the quality of fish for the final consumer. Some studies have been looking for biochemical (Venturini et al. 2018) and molecular markers (Zuanazzi et al. 2019) to prematurely identify the quality of the fish that will be slaughtered.

The timeline of the management of fish farming before the slaughter begins with capture in the tank, transport, arrival at the slaughterhouse, unloading, resting before slaughter, and finally, the stress of the slaughtering process. In these steps, the resting period can be crucial for restoring fish homeostasis (Fantini et al. 2020); however, densification can promote changes in the stress responses in Nile tilapia, which, consequently, can change the quality of the fillet (Hong et al. 2019). The increase in density causes changes due to stress mainly for Nile tilapia, fish of importance in aquaculture worldwide (Goes et al. 2018). Neotropical fish species also show undesirable meat quality responses when subjected to improper handling such as tambaqui Colossoma macropomum (Mendes et al. 2015) and matrinxã Brycon amazonicus (Venturini et al. 2018).

These pre-slaughter management stages are known as stress promoters in fish (Poli et al. 2005). However, the physiological and biochemical characteristics, such as mobilization of energy reserves in muscles and liver and changes in blood acid-base balance (Gatica et al. 2010) are not yet described in each of these stages. The physiological responses to stress depend on the nature of the stress (Ferreira \& Barcellos 2008); changes in heart rate, oxygen absorption, mobilization of energy substrates, and disturbance of the hydromineral balance (Fantini et al. 2020) can lead to exhaustion (Bagni et al. 2007; Goes et al. 2019). The changes promoted by the pre-slaughter are measured by the blood indirect indicators and reveal to us if there are conditions to obtain quality of meat of great quality (Anders et al. 2020; Venturini et al. 2018).

Furthermore, the depuration process can also be stressful to fish. This procedure is commonly performed after arrival at the slaughter unit to decrease the microbial load and remove the excess of specific compounds or unwanted contaminants from the fish's organism (Fontenele et al. 2013).

The Oreochromis niloticus (Nile tilapia) is a widespread species in aquaculture. Some studies report the effect of stress on the quality of fish (Goes et al. 2019; Venturini et al. 2018; Zuanazzi et al. 2019); however, some parameters have not yet been elucidated, mainly those associated with respiratory metabolism responses and their implications in preslaughter management.

In management situations that promote fish stress, intracellular oxygen supply is inadequate, with low ATP production, due to the lower energy yield of anaerobic respiration (Honorato et al. 2014). The concomitant production of lactate, electrolytic imbalance may be the result of inadequate management in the pre-slaughter of fish (Anders et al. 2020). Therefore, the use of blood variables may be indicative for rational management and adequacy of clearance time for reestablishment of fish homeostasis

Therefore, this study evaluated whether the resting density after Nile tilapia's transport shows responses in the respiratory and ionic dynamics related to stress parameters.

\section{Material and methods}

The fish are from a semi intensive production system, produced in excavated tanks. The fish were fed species-specific commercial feed during the production cycle. The experiment was conducted in a linear process scheme consisting of four steps, totaling four treatments with 10 repetitions per treatment (each fish was considered an experimental unit); 40 fish were sampled, with an average weight of $762 \pm 105 \mathrm{~g}$.

Steps:

I Control Group was exposed to minimal stress after removal from the water.

II After transportation. 
III After transportation and 1-hour rest at the stocking densities of $50 \mathrm{~kg}$ of live weight $/ \mathrm{m}^{3}$.

IV After transportation and 1-hour rest at the stocking densities of $300 \mathrm{~kg}$ of live weight $/ \mathrm{m}^{3}$.

The fish were initially removed from nurseries with the aid of a net and dip net and placed in a transporting box with constant aeration at a density of $200 \mathrm{~kg} / \mathrm{m}^{3}$. The transport water was added with 6 $\mathrm{mg} / \mathrm{L}$ sodium chloride, and the water temperature was lowered to $21{ }^{\circ} \mathrm{C}$ with ice. The fish were transported for one hour until arriving at the Laboratory of Analysis of Agricultural Products of the College of Agricultural Sciences of the Federal University of Grande Dourados.

In the laboratory, the fish were placed in polyethylene boxes with a capacity of $500 \mathrm{~L}$ and supplied with an artificial aeration system. Each experimental density (50 and $300 \mathrm{~kg}$ of live weight/ $\mathrm{m}^{3}$ ) was placed in separate boxes. The fish remained resting for one hour; 10 fish per density was sampled afterward.

Hemogasometric analyzes: Blood samples were collected by caudal puncture in $3 \mathrm{~mL}$ syringes (Ishikawa et al. 2010) and analyzed in a blood gas analysis device (Cobas HB121 - Roche Diagnostica Brasil, São Paulo, SP, Brazil). Sodium $\left(\mathrm{Na}^{+}\right)$, Potassium $\left(\mathrm{K}^{+}\right)$, and Chloride $\left(\mathrm{Cl}^{-}\right)$ions were measured. Respiratory blood parameters, such as $\mathrm{pH}, \mathrm{H}^{+}$, bicarbonate $\left(\mathrm{HCO}^{-} 3\right)$, partial oxygen pressure $\left(\mathrm{PO}_{2}\right)$, partial carbon dioxide pressure $\left(\mathrm{PCO}_{2}\right)$, and functional oxygen saturation $\left(\mathrm{SO}_{2}\right)$, were also determined (Fantini et al. 2020)

Evaluation of biochemical parameters: Glucose and creatinine analyses were conducted in blood samples collected by vena caudal puncture using $3 \mathrm{~mL}$ heparinized syringes. These analyses were performed using commercial kits (Gold Analisa Diagnóstica $\left.{ }^{\circledR}\right)$, according to the manufacturer's instructions, and readings of results were conducted on a semi-automatic spectrophotometer (BIOPLUS S200). The enzymatic parameters related to lactate (Lactate Kit; Katal Biotecnológica Ind. Com. Ltda. Minas Gerais, MG, Brazil) were measured at 546 nm (RA-XT; Technicon Instrument Corp, Tarrytown, NY).

Statistical analysis: The results were subjected to analysis of variance (ANOVA) using the General Linear Models procedure in the STATISTICA $7.1^{\circledR}$ software (Statsoft Inc., Tulsa, OK, USA) at a 5\% level of significance. The Tukey test was applied to verify differences between means when significant differences $(\mathrm{p}<0.05)$ were observed. Data were expressed as mean \pm standard error.

\section{Results}

The fish had sanitary conditions that guaranteed their quality for transportation, slaughter and commercialization. After transport, the fish remained in hypoventilation due to high $\mathrm{PCO}_{2}$ values, demonstrating compensatory respiratory acidosis because the $\mathrm{pH}$ maintained the homeostatic control with its buffer function, along with $\mathrm{CHCO}_{3}$ stability (Table I).

Hyperkalaemia and excessive blood nitrogen metabolite are showed on Table II. The fish in the group kept at rest in the density of $50 \mathrm{Kg} / \mathrm{m}^{3}$ showed respiratory acidosis, high $\mathrm{pH}$ compensation (Table I), hypercalcemia, increased glycemia, and decreased creatinine compared to the control group. The fish group with the density of $300 \mathrm{Kg} / \mathrm{m}^{3}$ remained in respiratory acidosis and increased lactate values compared to the control group (Table I). No lactate alterations were observed in any of the resting densities.

\section{Discussion}

The stocking density during the resting process may have an influence on the well-being of fish, restoring physiological characteristics to those before the handling of transport. Management studies are critical to optimize the fish production chain (Fantini et al. 2020; Zuanazzi et al. 2019). In this experiment, we demonstrate that the stocking density can influence respiratory function and affect homeostasis.

Changes in respiratory rates that result in differences in oxygen saturation can be considered a response to environmental changes (Honorato \& Nascimento, 2016) and fish management (Fantini et al. 2020). In this study, the ventilatory responses were insufficient to maintain the oxygen dynamics immediately after transport in fish subjected to the resting density of $300 \mathrm{~kg} / \mathrm{m}^{3}$, resulting in compensatory respiratory acidosis due to the increase of blood $\mathrm{HCO}_{3}$. The decrease in blood $\mathrm{pH}$ is compensated by the rise in blood regulation by the level of $\mathrm{HCO}_{3}$ (Foss et al. 2007; Jia et al. 2021).

The fish at the resting density of $50 \mathrm{Kg} / \mathrm{m}^{3}$ remained at baseline values after transport, suggesting that the acid-base balance was restored. It is noteworthy that the resting density effectively restores homeostasis, demonstrating blood $\mathrm{pH}$ values close to neutrality. 
Table I. Mean \pm SE respiratory parameters of Nile tilapia Oreochromis niloticus subjected to transport capture management and pre-slaughter rest density.

\begin{tabular}{|c|c|c|c|c|c|}
\hline \multirow[b]{2}{*}{ Parameters } & \multirow{2}{*}{$\begin{array}{c}\text { Control Group } \\
\text { removal from } \\
\text { the water }\end{array}$} & \multirow{2}{*}{$\begin{array}{c}\text { After } \\
\text { transportation }\end{array}$} & \multicolumn{2}{|c|}{ Stocking densities } & \multirow[t]{2}{*}{ P-value } \\
\hline & & & $50 \mathrm{~kg} / \mathrm{m}^{3}$ & 300 kg/m ${ }^{3}$ & \\
\hline $\mathrm{pH}$ & $7,26 \pm 0,03 \mathbf{b}$ & $7,19 \pm 0,02 \mathbf{b}$ & $7,42 \pm 0,04 \mathbf{a}$ & $7,22 \pm 0,08 \mathbf{b}$ & 0,0033 \\
\hline${ }^{1} \mathrm{PCO}_{2}(\mathrm{mmHg})$ & $25,34 \pm 1,37 \mathbf{a}$ & $32,45 \pm 0,96 \mathbf{b}$ & $32,36 \pm 7,94 \mathbf{a b c}$ & $41,77 \pm 6,42 c$ & 0,0872 \\
\hline${ }^{2} \mathrm{PO}_{2}(\mathrm{mmHg})$ & $98,56 \pm 32,03 \mathbf{a b}$ & $131,54 \pm 24,91 \mathbf{a}$ & $36,24 \pm 7,87 \mathbf{c}$ & $37,01 \pm 3,09 c$ & 0,0221 \\
\hline${ }^{3} \mathrm{SO}_{2}(\%)$ & $60,90 \pm 7,41 \mathbf{a}$ & $79,56 \pm 4,35 \mathbf{b}$ & $59,04 \pm 5,31 \mathbf{a}$ & $45,96 \pm 1,81 c$ & 0,0021 \\
\hline${ }^{4} \mathrm{HCO}_{3}(\mathrm{mmol} / \mathrm{L})$ & $11,17 \pm 0,82 \mathbf{b}$ & $12,15 \pm 0,45 \mathbf{b}$ & $11,26 \pm 0,64 \mathbf{b}$ & $18,16 \pm 1,40 \mathbf{a}$ & 0,0000 \\
\hline
\end{tabular}

Means in the same row with different letters indicate statistical difference by the Tukey test $(\mathrm{p}<0.05)$. 1partial carbon dioxide pressure $\left(\mathrm{PCO}_{2}\right), 2$ partial oxygen pressure $\left(\mathrm{PO}_{2}\right), 3$ functional oxygen saturation $\left(\mathrm{SO}_{2}\right)$ and 4 bicarbonate $\left(\mathrm{HCO}_{3}^{-}\right)$.

Table II. Mean \pm SE blood electrolytes of Nile tilapia Oreochromis niloticus subjected to transport capture management and pre-slaughter rest density.

\begin{tabular}{|c|c|c|c|c|c|}
\hline \multirow{2}{*}{ Parameters } & \multirow{2}{*}{$\begin{array}{l}\text { Control Group } \\
\text { removal from the } \\
\text { water }\end{array}$} & \multirow{2}{*}{$\begin{array}{c}\text { After } \\
\text { transportation }\end{array}$} & \multicolumn{2}{|c|}{ Stocking densities } & \multirow{2}{*}{ P-value } \\
\hline & & & $50 \mathrm{~kg} / \mathrm{m}^{3}$ & $300 \mathrm{~kg} / \mathrm{m}^{3}$ & \\
\hline \multicolumn{6}{|c|}{ Plasmatic ions (nmol.L $\left.{ }^{-1}\right)$} \\
\hline $\mathrm{Na}^{+}$ & $151,14 \pm 4,59$ & $150,19 \pm 2,76$ & $143,97 \pm 4,76$ & $136,71 \pm 1,83$ & 0,0510 \\
\hline $\mathrm{K}^{+}$ & $3,72 \pm 0,19$ & $3,05 \pm 0,19$ & $3,29 \pm 0,29$ & $3,04 \pm 0,30$ & 0,1287 \\
\hline $\mathrm{Ca}^{+}$ & $7,13 \pm 0,10 \mathrm{c}$ & $7,74 \pm 0,05 a$ & $7,57 \pm 0,13 \mathrm{ab}$ & $7,34 \pm 0,11 b c$ & 0,0002 \\
\hline \multicolumn{6}{|c|}{ Biochemical parameters (mg/dL) } \\
\hline Glucose & $91,16 \pm 8,12 a$ & $128,86 \pm 13,76 b$ & $159,04 \pm 12,76 \mathrm{c}$ & $122,13 \pm 5,88 b$ & 0,0020 \\
\hline Lactate & $1,13 \pm 0,11$ & $1,36 \pm 0,27$ & $1,42 \pm 0,23$ & $1,26 \pm 0,12$ & 0,7488 \\
\hline Creatinine & $0,22 \pm 0,03 b$ & $0,40 \pm 0,05 a$ & $0,17 \pm 0,01 b$ & $0,41 \pm 0,04 a$ & 0,0000 \\
\hline
\end{tabular}

Means in the same row with different letters indicate statistical difference by the Tukey test $(\mathrm{p}<0.05)$.

Among the most pronounced changes in management associated with transport is plasma glucose (Hong et al. 2019). Stress-related hyperglycemia is described in tilápia (Oreochromis niloticus) and surubim (Pseudoplatystoma sp) (Fantini et al. 2020; Goes et al. 2019; Venturini et al. 2018) because increased serum glucose in fish is a common reaction to transport (Acerete et al. 2004; Hong et al. 2019). However, the restoration of glucose levels to baseline values is required because it can interfere with the quality of fish to be marketed (Fantini et al. 2020; Sampaio \& Freire 2016). Acute hyperglycemic response has been reported for fish submitted to exhaustive swimming (Olsen et al. 2008). The energy demand for maintaining respiratory rates is high, so it is observed that circulating glucose rates are higher in fish subjected to stress (Honorato et al. 2014) to maintain energy production.

The sodium and potassium balance did not show a difference in the electrolyte balance. Although these parameters are not reported in the transport stress assessment, they reflect homeostasis in fish (Sampaio \& Freire 2016). The fish submitted to transport showed increased plasmatic calcium and creatinine as the result of muscle contraction. The group in the stocking density of $300 \mathrm{Kg} / \mathrm{m}^{3}$ showed an increase in creatinine compared to the control and the $50 \mathrm{Kg} / \mathrm{m}^{3}$ storage density groups. Creatinine is a metabolite of the muscle tissue and indicates muscle protein catabolism (Yousefi et al. 2016). Fish subjected to stressing conditions tend to mobilize 
energy sources by increasing the concentrations of lactate (Inoue et al. 2019) and creatinine (Hong et al. 2019) in the muscles. Creatinine is an exclusive metabolite of muscles, there is evidence that this measurement estimates body mass (Toledo et al. 2015; Akçakaya et al., 2016) However, for fish creatinine would be not used as a biochemical marker (Yousefi et al. 2016; Hong et al. 2019). Although it is not a specific marker for determining muscle changes or damage it can along with the other analyses comparing an indicative picture of muscle injury.

Conclusion, the resting density of $50 \mathrm{Kg} / \mathrm{m}^{3}$ restores respiratory functions and homeostasis in fish, being recommended for Nile tilapia to reduce pre-slaughter stress and increase marketed fillets' quality.

\section{Acknowledgement}

We are indebted to the Faculdade de Ciências Agrarias at Federal University of Grande Dourados, to the Laboratory of Laboratory of Adaptive Biochemistry the fish for facilities and technical support that allowed us to carry on the present investigation. In particular, we would like to acknowledge the all colleagues of the Laboratory of Adaptive Biochemistry the fish. We also thank CAPES, CNPq and for financial support.

\section{References}

Acerete, L, Balasch, JC, Espinosa, E, Josa, A, Tort, L 2004. Physiological responses in Eurasian perch (Perca fluviatilis, L.) subjected to stress by transport and handling. Aquaculture, 237: 167-178.

https://doi.org/10.1016/j.aquaculture.2004.03. 018

Akçakaya, MO, Yörükoğlu, AG, Aydoseli, A, Aras, Y, Sabanci, PA, Altunrende, ME, Dolgun, M, Göker, B, Şencan, F, Ali, A, Sencer, A, 2016. Serum creatine phosphokinase levels as an indicator of muscle injury following lumbar disc surgery: Comparison of fully endoscopic discectomy and microdiscectomy. Clinical Neurology and Neurosurgery, 145: 74-78. https://doi.org/10.1016/j.clineuro.2016.04.004

Anders, N, Eide, I, Lerfall, J, Roth, B, Breen, M, 2020. Physiological and flesh quality consequences of pre-mortem crowding stress in Atlantic mackerel (Scomber scombrus). PLoS One, 15: 1-25. https://doi.org/10.1371/journal.pone.0228454
Bagni, M, Civitareale, C, Priori, A, Ballerini, A, Finoia, M, Brambilla, G, Marino, G, 2007. Pre-slaughter crowding stress and killing procedures affecting quality and welfare in sea bass (Dicentrarchus labrax) and sea bream (Sparus aurata). Aquaculture , 263: 52-60.

https://doi.org/10.1016/j.aquaculture.2006.07. 049

Fantini, LE, Rodrigues, RA, Honorato, CA, Dos Reis Goes, ES, Ferraz, ALJ, Ferreira De Lara, JA, Hanson, T, Meldau De Campos, C, 2020. Resting time before slaughter restores homeostasis, increases rigor mortis time and fillet quality of surubim Pseudoplatystoma spp. PLoS One , 15. https://doi.org/10.1371/journal.pone.0233636

Ferreira, D, Barcellos, LJG, 2008. Enfoque combinado entre as boas práticas de manejo e as medidas mitigadoras de estresse na piscicultura. Boletim do Instituto de Pesca , 34: 601-611.

Fontenele, RMM, Santos, ES dos, Mota, S, 2013. Índice de rigor mortis de tilápias do nilo abatidas de diferentes formas após cultivo em esgoto doméstico tratado. Conexões - Ciência e Tecnologia , 7: 61-72.

Foss, A, Imsland, AK, Roth, B, Schram, E, Stefansson, SO, 2007. Interactive effects of oxygen saturation and ammonia on growth and blood physiology in juvenile turbot. Aquaculture, 271: 244-251. https://doi.org/10.1016/j.aquaculture.2007.06. 025

Gatica, MC, Monti, GE, Knowles, TG, Gallo, CB, 2010. Muscle $\mathrm{pH}$, rigor mortis and blood variables in Atlantic salmon transported in two types of well-boat. Veterinary Record 166: 45-50. https://doi.org/10.1136/vr.c71

Goes, ES dos R, De Lara, JAF, Gasparino, E, Goes, MD, Zuanazzi, JSG, Lopera-Barrero, NM, Rodriguez, M del PR, de Castro, PL, Ribeiro, RP, 2018. Effects of transportation stress on quality and sensory profiles of nile tilapia fillets. Scientia Agricola, 75: 321-328. https://doi.org/10.1590/1678-992x-2016-0387

Goes, ES dos R, Goes, MD, de Castro, PL, de Lara, JAF, Vital, ACP, Ribeiro, RP, 2019. Imbalance of the redox system and quality of tilapia fillets subjected to pre-slaughter stress. PLoS One, 14 : 1-15. https://doi.org/10.1371/journal.pone.0210742 
Hong, J, Chen, X, Liu, S, Fu, Z, Han, M, Wang, Y, Gu, Z, Ma, Z, 2019. Impact of fish density on water quality and physiological response of golden pompano (Trachinotus ovatus) flingerlings during transportation. Aquaculture, $\quad$ 507: 260-265. https://doi.org/10.1016/j. aquaculture.2019.04.040

Honorato, CA, Dambros, A, Marcondes, VM, Nascimento, CA, 2014. Utilização do eugenol em Jundiá da Amazônia (Leiarius marmoratus): Implicações na sedação e avaliação hemogasométrica. Semina Agraria, 35: 2759-2768. https://doi.org/10.5433/16790359.2014v35n5p2759

Honorato, CA, Nascimento, CA, 2016. Respiratory metabolism of 'Carassius auratus' in different concentrations of eugenol. Revista Brasileira de Saúde e Produção Animal, 17. https://doi.org/10.1590/S151999402016000300019

Inoue, LAKA, Hackbarth, A, Arberláez-Rojas, G, Moraes, G, 2019. Growth performance and metabolism of the Neotropical fish Piaractus mesopotamicus under sustained swimming. Aquaculture, $\quad$ 511: 734219. https://doi.org/10.1016/j.aquaculture.2019.734 219

Ishikawa, MM, Pádua, SB De, Satake, F, Pietro, PS De, Hisano, H, 2010. Procedimentos Básicos para Colheita de Sangue em Peixes. Circ. Técnica 17, 1-8.

Jia, Y, Wang, J, Gao, Y, Huang, B, 2021. Hypoxia tolerance, hematological, and biochemical response in juvenile turbot (Scophthalmus maximus. L). Aquaculture , 535: 736380. https://doi.org/10.1016/j.aquaculture.2021.736 380

Mendes, JM, Inoue, LAKA, De Jesus, RS, 2015. Influence of transport stress and slaughter method on rigor mortis of tambaqui (Colossoma macropomum). Brazilian Journal of Food Technology, 18: 162-169. https://doi.org/10.1590/1981-6723.1115

Olsen, RE, Sundell, K, Ringø, E, Myklebust, R, Hemre, G-I, Hansen, T, Karlsen, Ø, 2008. The acute stress response in fed and food deprived Atlantic cod, Gadus morhua L. Aquaculture,
280:

232-241. https://doi.org/10.1016/j.aquaculture.2008.05.006

Poli, BM, Parisi, G, Scappini, F, Zampacavallo, G, 2005. Fish welfare and quality as affected by pre-slaughter and slaughter management. Aquaculture International, 13: 29-49. https://doi.org/10.1007/s10499-004-9035-1

Refaey, MM, Tian, X, Tang, R, Li, D, 2017. Changes in physiological responses, muscular composition and flesh quality of channel catfish Ictalurus punctatus suffering from transport stress. Aquaculture, 478: 9-15. https://doi.org/10.1016/j.aquaculture.2017.01.026

Sampaio, FDF, Freire, CA, 2016. An overview of stress physiology of fish transport: changes in water quality as a function of transport duration. Fish and Fisheries, 17: 1055-1072. https://doi.org/10.1111/faf.12158

Toledo, PS De, Júnior, MD, Fernandes, WR, Magone, M, 2015. Serum activities of aspartate aminotransferase, creatine kinase and lactate dehydrogenase in arabian horses submitted to standard incremental exercise test. Brazilian Journal of Veterinary Research and Animal Science, 44(3): 183190

Venturini, FP, Vargas Baldi, SC, Parisi, G, Costa, TD, Rucinque, DS, Pires Melo, M, Viegas, EMM, 2018. Effects of different stunning methods on blood markers and enzymatic activity of stress responses of tilapia (Oreochromis niloticus). Italian Journal of Animal Science, 17: 1094-1098. https://doi.org/10.1080/1828051X.2018.1426396

Yousefi, M, Paktinat, M, Mahmoudi, N, PérezJiménez, A, Hoseini, SM, 2016. Serum biochemical and non-specific immune responses of rainbow trout (Oncorhynchus mykiss) to dietary nucleotide and chronic stress. Fish Physiology and Biochemistry, 42:

1417-1425. https://doi.org/10.1007/s10695-016-0229-z

Zuanazzi, JSG, de Lara, JAF, Goes, ESDR, de Almeida, FLA, de Oliveira, CAL, Ribeiro, RP, 2019. Anoxia stress and effect on flesh quality and gene expression of tilapia. Food Science and Technology, 39: 195-202. https://doi.org/ 10.1590/fst.00518

Received: December 2020

Accepted: April 2021

Published: November 2021 